\title{
Nピyクス 頭痛：診断と治療の進歩
}

\section{V.頭痛の診断と治療 4. 慢性硬膜下血腫の頭痛}

吉本 高志* 小野 靖樹** 藤原 悟***

\section{はじめに}

慢性硬膜下血腫 (chronic subdural hematoma 以下 CSH) の成因は炎症説，外傷説から特発説に いたるまで種々あり，まだ現在でも不明な点が多 い. 軽微な外傷後, 3 週 3 月後頃上り症状を呈 してくるのが一般的であるが, 10 20\%は特発性, 非外傷性に発生する。病巣部位は大脳半球表面で, 約15\%前後は両側性で, 頭蓋底部やテント下はま れである. 男性に圧倒的に多発し(約 9 割)，中年 以上の大酒家に多い傾向があり，約半数が60歳以 上である. 発生頻度は年間人口 10 万人につき 1 ～2人とされるが，高龄者ではさらに高頻度で， 70 歳以上は 7 人前後といわれる ${ }^{122)}$.

\section{1. 症状}

頭蓋内圧六進症状としての頭痛と精神症状, 片 麻痺が三大症状である，同一例でこれらが種々の 程度に混在することもあるが, 若年者は頭痛, 5っ 血乳頭が多く，高齢者に精神症状，片麻痺が多い

*よしもとたかし，**おの やすき, 東北大学脳 神経外科, ***らじわらさとる, 厷南病院脳神経外 科
とされる. Plumらが49例のCSH患者の頭蓋内圧 (intracranial pressure以下ICP) を測定したとこ ろ,ICP六進例は25例 (51\%) に過ぎなかったとい ら報告 ${ }^{3)}$ ) やBrodersenらの 7 例のCSH患者では らっ血乳頭, ICP六進例は無かったとする報告4が ある。またCSH患者に対する腰椎穿刺による脳资 髄液圧測定でも半数以上が正常圧であり, ICP方 進による症状はCSHに一般的でないとするすの， あるいはCSH 216例中，らっ血乳頭は $22 \%$ に見ら れたに過ぎないとするMcKissockらの報告5)出 されている. 我々も, 穿頭手術施行時に血腫被膜 内の圧が全く高くない例も多数経験している. 従って, CSHの症状にはICP六進によるものとは いえない例が多数あると考学られる。

頭痛に関しても同様で, ICP六進によるものの ほか，血腫による硬膜や橋静脈 (bridging vein) などの痛覚感受性組織の偏位や牽引によるものが かなり多いと考学られる。

頭痛の性質についての明確な記載はなく, 当科 例でも頭重感からズキズキする痛みをで一定の傾 向はなく, 程度もごく軽度のものからかなり強い 痛みのものまでさまざまで, 症状だけでCSHと診 断するのは困難である。ただし，軽度の麻㽻，精 神症状などを伴う頭痛の場合には常に本疾患を念 頭に入れ，診断を進めるべきである，精神症状と 
表 1. 当科でCT, SPECTを施行した慢性硬膜下血腫21例

頭痛群：10例 (平均61.6歳) 両側珄 $60 \%$

麻盘群：6例 (平均78.8歳) 両側性 0\%

精神症状群：5例（平均74.2歳）両側性 $40 \%$

いらのは概括的表現であり，変動する意識障害， 記憶・記銘力障害, 痴呆, 精神活動の遅純, 性格 変化など多彩であるが, 尿失禁を伴うこともあり, 症状の上からは他疾患と鑑別が難しいこともあ る. とくに早発珄痴呆, 正常圧水頭症, TIA (transient ischemic attack), 単なる老化と診断された り，慢性アルコール中毒, “妄，精神錯乱とさ れ，精神科に入院し発見される例もある。

大脳の巣症状としては, 軽度〜中等度の片麻痺, 失語が多い.

また，急激に発症し，巣症状や意識障害をきた し, 脳卒中と誤診される例もあり(約 $5 \%$ ), 注意 を要する.これらすでにに存在する血腫腔内への 新鮮出血が起こったことによる.

当科でCT (computed tomography), 脳循環測 定 (single photon emission computed tomography以下SPECT) を施行したCSH 21例を主症状 により頭痛群, 麻盘群, 精神症状群の 3 群に分け ると, 平均年齢は61.6歳, 麻㽻群78.8歳, 精神症 状群は74.2歳と頭痛群が若年傾向にあった（表
1). また病巣が両側性例は頭痛群が 6 割でとくに 麻痺群に比し，高い頻度を示した。

\section{2. 診断}

以前には脳血管撮影も行われたが, 現在ではCT による診断が簡便かつ一般的である.CTでは血腫 が頭蓋骨内板を凸面にした凸レンズ状で脳表側は それに平行または直線状を呈し，血腫の性状・年 齢により低吸収域，脳と等吸収域，あるいはやや 高い吸収域を示す（図 1a〜c)。これらのほか，低 吸收域の中に新しい出血による高吸収域や液面形 成を伴った混合吸収域を呈する例もある（図 2a， b). 等吸収域のものは，正中構造偏位，患側脳室 の狭小化や消失のみが認められ，血腫そのものの 存在や脳表との境界は不明瞭である(図 1b). 両側 性で等吸収域を示すものは，正中構造の变化も少 なく,ことに病巣が頭頂部にある場合はCTでは診 断が困難で(図 3a)，次に述べる磁気共鳴断層撮影 (magnetic resonance imaging以下MRI) が有力 である。

一般にCSHはMRIのほうがCTょりも診断的価 值が高い，血腫の性状にもよるが，概して $\mathrm{T}_{1}, \mathrm{~T}_{2}$ 強調像とも高信号域を示す(図 $3 a \sim c$ ). ことに $T_{1}$ 強調像は血液のメトへモグロビンによる緩和時間
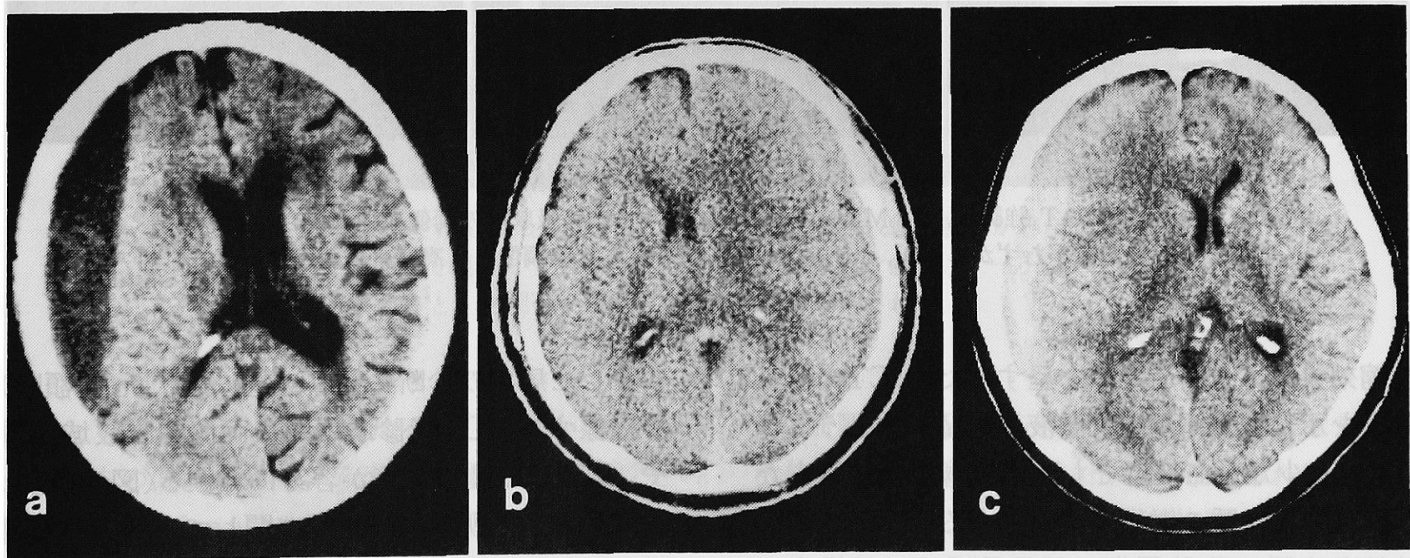

図 1a〜c. 慢性硬膜下血腫のCT所見

血腫の性状, 血腫の年齢等により, a : 低吸収域, b : 等吸収域, $\mathbf{c}$ ：やや高吸収域を示するのがある. aは精神症状 (痴呆) 例 b, ck頭痛例 

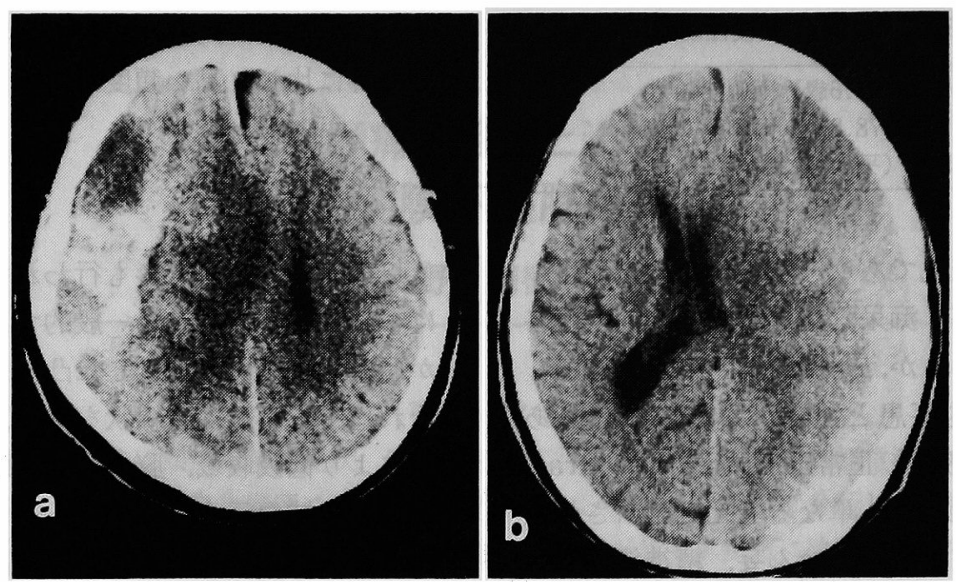

図 2a，b. a：低吸収域血腫の中に新しい出血をきたし，症状の急性増悪をきたした 例. b：低吸収域の中に高吸収域が液面形成している。
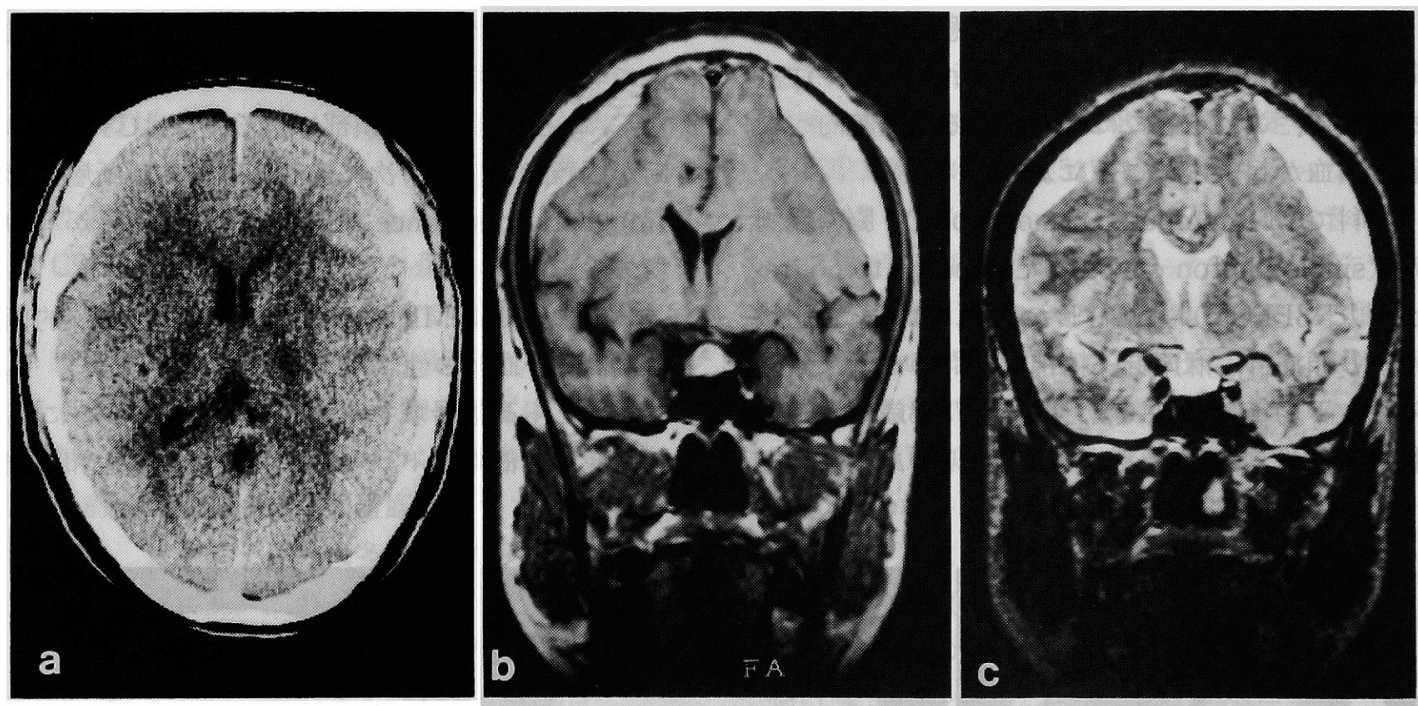

図 3a〜c. 慢性硬膜下血腫のCT とMRI

$\mathbf{a}: \mathrm{CT}, \mathbf{b}: \mathrm{MRI}$ の $\mathrm{T}_{1}$ 強調像, $\mathbf{c}: \mathrm{MRI}$ の $\mathrm{T}_{2}$ 強調像. CTでは等吸収域の両側血腫の場合, 正中構造 の偏位もなく診断がむずかしいが，MRIでは容易で， $\mathrm{T}_{1}, \mathrm{~T}_{2}$ 強調像とも高信号域を呈する。

短縮効果により高信号域を呈するため, CTで低吸 収域を示し硬膜下水腫（㵦液の貯留）のように見 えても, 少ない血液量でも $\mathrm{T}_{1}$ 強調像で高信号とな り，血腫と水腫の鑑別が容易である.もちろん， 純粋な水腫は $\mathrm{T}_{1}$ 強調像で低信号域として描出さ れる(図 4a，b).さらにMRIではCTと違い，骨 による偽像が全くないため, CSHのように頭蓋骨
に接した病巣の診断に優れ，特に冠状断(前額断) で撮像するとCTで診断困難な両側等吸収域血腫 や，頭頂部血腫の存在が容易にわかる(図 $5 \mathrm{a}, \mathrm{b}$ ). 症状と検査所見との相関に関して, 前述の当科 の 3 群21例の検討では, まずCTによると頭痛群は 精神症状群に比べ明らかに脳萎縮が軽度の傾向が みられた(図 1 )。これは頭痛群が平均年齢が若い 

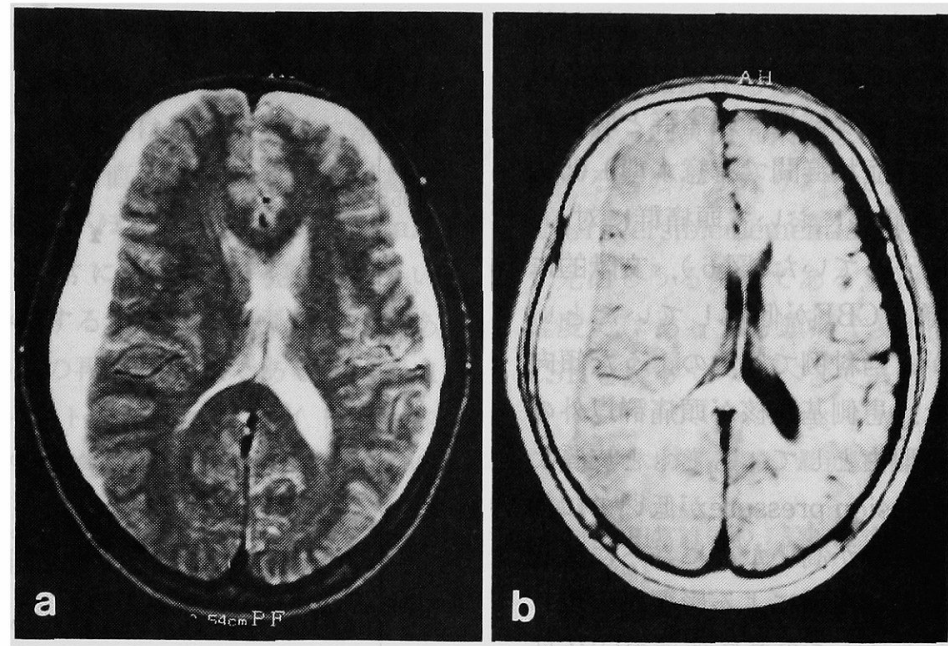

図 4a, b. 右側血腫, 左側水腫のMRI

$\mathbf{a}: \mathrm{T}_{2}$ 強調像では両側高信号域となり, 両者の鑑別は困難であるが, $\mathbf{b}: \mathrm{T}_{1}$ 強調像では 血腫が高，水腫が低信号域となり，鑑別が容易である.
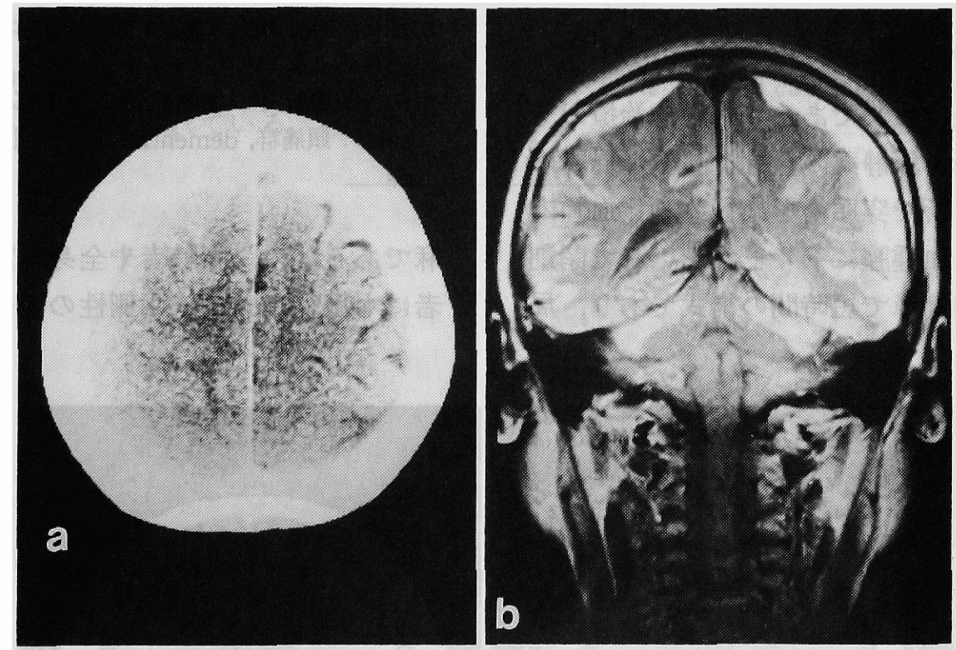

図 5a,b. a :CTでは脳溝の消失などにより, 右側の等吸収域血腫がかららじて診断さ れるが，頭頂部まで観察しても対側の血腫の存在は確認できない。一方，b:MRIでは 冠状断で観察すると, 対側の小血腫の存在も容易に確認される.

こととも関連すると考兄られるが，萎縮が軽度ゆ 之頭蓋内の間隙が狭く, 少量の血腫でも痛覚感受 性組織にtensionが加わりやすいためと思われる。 一方, 精神症状群は高齢者でかつ萎縮が強いこと から, 頭蓋内間吵は広いものの脳神経細胞自体の 機能が既に低下しているところに圧迫が加わるた
め, 血腫によるtensionのための頭痛症状よりも脳 機能低下の症状が前面に出ると考兄られる。

次にSPECTによる脳循環の検討では，画像上 は麻痺群に病巣側大脳の若干の脳血流低下傾向が 見られたが，客観評価のため前頭部 $(\mathrm{F})$ ，側頭部 ( $\mathrm{T})$ ，頭頂部 $(\mathrm{P})$ ，基底核 (B) の関心領域を設定 
し，健側に対する患側のカウント比による相対的 脳血流（\%CBF）を求めた。両側例は血腫の多い サイドを患側とした。その結果，頭痛群と麻痷群 間执よび頭痛群と精神症状群間で有意水準 0.05 に て検定したところ, 基底核に执いて頭痛群に対し， 他の 2 群で有意に低下していた(図 6). 文献的に は麻㽻例で大脳皮質のCBFが低下していたとい ら報告もみられるが，当科例ではそのような傾向 は認められなかった。患側基底核が頭痛群以外の 2 群で低下していた理由として，もともと皮質よ り皮質下, 白質がperfusion pressureが低いのに加 え, この 2 群の平均年齢が高いためにさらに基底 核部のCBFが低くなり，血腫による影響が出現し やすいことが考兄られる。この基底核部のCBF低 下による同部の機能低下のため種々の神経・精神 症状をきたす可能性も有り得ると思われる。

\section{3. 治療}

自然吸収・消失はまれである．外科的治療が一 般的であり，鎮痛・鎮静薬の全身投与下に局所麻 酔で 1 ないし 2 力所で穿頭術を施行する. 血腫内 容を洗浄除去し，血腫腔にドレーンをいれて閉創 するという比較的簡単で短時間の術式であり，局

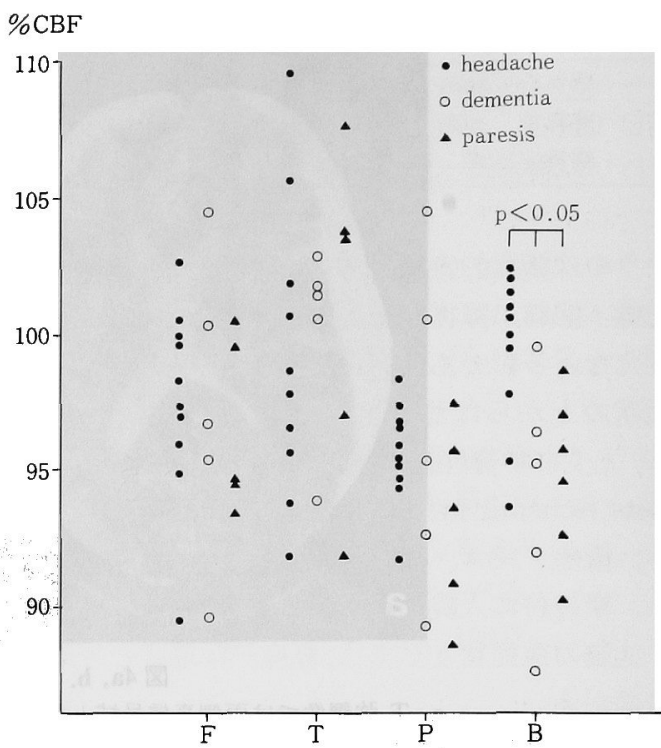

図 6. 健側に対する患側の相対的脳血流(\%CBF). 基 底核 (B) に㧊いて, 頭痛群と麻瘦群間, 頭痛群と精神 症状群間で有意差あり, 頭痛群に比して他の 2 群は低 下していた。

$\mathrm{F}$ : 前頭部, $\mathrm{T}$ ：側頭部, $\mathrm{P}$ ：頭頂部, $\mathrm{B}$ ：基底核, headache : 頭痛群, dementia : 精神症状群, paresis：麻疸 群

麻であるため，高齢者や全身状態の十分でない患 者にも施行できる，両側性の場合は，一度に両側
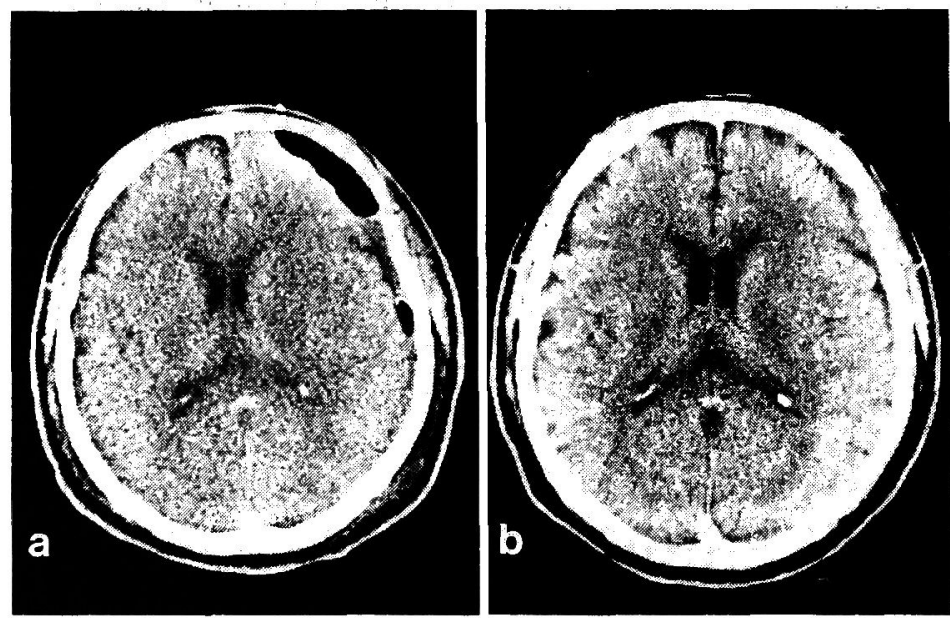

図 7a, b. 図 1bと同一症例の術後のCT

$\mathbf{a}$ : 術後 5 日目, 血腫腔に空気と洗浄液が残存しているが, 既に脳室の偏位も改善して いる. b：術後 2 週間目, 全く正常のCT像となった。 
の血腫除去を行う、ドレーンは術後CTで血腫が無 くなるのを確認し拔去するが，たいていは数日の 留置で齐さ，術後しばらくは血腫除去腔に洗浄水 や空気が残存するが，術直後より麻疩などが劇的 に改善・消失する場合が注とんどである（図 7a，

b). 手術成績は非常に良く，再発す少ない (10 15\%)方，再発する場合は術後早期の双であ り，長期を経てからの再発はまれである。非観血 的潦法としてマンニトールやステロイドを投与 し，血腫が消失した報告もあるが，治療にやや長 期を要することと，定状消失に時間がかかるなど の理由から, 術式も簡単な上記手術が勧められる。

\section{おわりに}

高齡化社会となった現在, 精神症状, ことに痴 呆様症状を呈する患者に遭遇する機会がすするす 多くなると思われるが，我が国ではこの中には本 態性痴呆 (Alzheimer型痴呆)上りも二次性痴呆の 占める割合が大きいと考光られている、後者の原
因の中に慢性硬膜下血腫 (CSH) が含まれるが, それだけに単なる痴呆とされ，放置される可能性 がある。二次性㾰呆は原因を適切に治療すれば治 癒するものがかなりあるが，なかであCSHは海外 でも reversible dementia上され，簡単な手術によ り完治しらる疾患である.痴呆様症状に付随して, 軽度ではあっても頭痛や巣症状を呈する場合は CSHを疑ってみるべきであろう。

\section{文献}

1) 鈴木二郎 (編): 最新脳神経外科学, 理工学社, 1988.

2)太田富雄(編)：脳神経外科学，改訂 6 版, 金芳堂, 1991.

3) Plum F, Posner JB: Diagnosis of Stupor and Coma, 2nd ed, FA Davis Company, Philadelphia, p102, 1972.

4) Brodersen P, Gjerris F: Regional cerebral blood flow in patients with chronic subdural hematomas. Acta Neurol Skandinav 51:233, 1975.

5) McKissock W, et al: Subdural hematoma. A review of 389 cases. Lancet $4: 1365,1960$. 